\title{
LA ICONOGRAFÍA DE SAN JUAN EVANGELISTA EN LA ESCULTURA GRANADINA DEL NATURALISMO ${ }^{1}$.
}

\author{
JOSÉ ANTONIO PEINADO GUZMÁN \\ Universidad de Granada
}

\begin{abstract}
Resumen
Una de las iconografías hagiográficas más cuantiosa en el arte cristiano es la de San Juan Evangelista. Mediante este artículo se pretende repasar la misma en los inicios de la escultura de la escuela granadina a finales del siglo XVI y principios del XVII. El modelo reiterado casi en exclusiva será el relacionado con la escena del Calvario. Los sucesos históricos y el contexto peculiar de la Granada recién conquistada, determinarán el uso de este prototipo de imagen en favor de la evangelización del territorio. Junto con esculturas sobradamente conocidas, en este periplo por el tipo iconográfico joánico, se dan a conocer piezas nuevas intentando proponer una atribución a las mismas.
\end{abstract}

Palabras clave

Escultura, Granada, Siglos XVI-XVII; Iconografía; Pablo de Rojas; Bernabé de Gaviria; Alonso de Mena.

\section{THE ICONOGRAPHY OF SAINT JOHN THE EVANGELIST IN THE GRANADA SCULPTURE DURING NATURALISM.}

\section{Abstract}

One of the most important hagiographic iconographies in Christian art is that of Saint John the Evangelist. By means of this article it is tried to review it in the beginnings of the sculpture of the Granada school at the end of century 16th and the start of the 17th. The model repeated almost exclusively will be related to the scene of Calvary. The historical events and the peculiar context of the recently conquered Granada, will determine the use of this prototype of sculpture in favor of the evangelization of the territory. Along with well-known sculptures, in this journey by joanic iconographic type, new pieces are presented trying to propose an attribution to them.

\section{Keywords}

Sculpture; Granada; 16th-17th centuries; Iconography; Pablo de Rojas; Bernabé de Gaviria; Alonso de Mena;

\footnotetext{
${ }^{1}$ Mi agradecimiento al Dr. D. Isaac Palomino Ruiz, por sus consejos, observaciones y orientaciones siempre acertadas.
} 


\section{Introducción}

San Juan Evangelista, según narran los evangelios, era hijo del pescador Zebedeo, siendo llamado por Jesús para que le siguiera ${ }^{2}$. Constituye uno de los doce apóstoles, por tanto ${ }^{3}$. Está presente en diversos milagros de Cristo como el de la suegra de $\mathrm{Pedro}^{4}$ o el de la hija de Jairo ${ }^{5}$. Formando el grupo de los tres discípulos favoritos de Jesús, está presente en el momento de la Transfiguración ${ }^{6}$ o en el sufrimiento del huerto de Getsemaní ${ }^{7}$. Es de los pocos discípulos que aparece dialogando con el Maestro con frecuencia ${ }^{8}$. Existe tanta familiaridad entre Cristo y él, que es considerado como el "discípulo amado". Detalle de esto lo refleja el que en la Última Cena, se nos presente a Juan recostado en el pecho de Jesús, siendo él quien pregunta acerca de quién será el traidor ${ }^{10}$. Finalmente, en el momento de la crucifixión, se halla al pie de la cruz junto con María, quedándose por mandato del Hijo, a cargo de ella ${ }^{11}$.

Según la tradición ${ }^{12}$, tras la dispersión de los apóstoles, Juan marcha a Asia estableciéndose en Éfeso, lugar donde se establece junto con la madre de Jesús hasta la muerte de ésta, que habría ocurrido unos veintitrés años después de la de su Hijo. Allí es detenido ya anciano, en tiempos del emperador Domiciano, siendo arrojado en una tinaja con aceite hirviendo. Del suplicio saldría completamente indemne. Según Ribadeneira, "el aceite hirviente se convirtió en rocío del cielo y Juan salió de la cuba más sano de lo que entrara" ${ }^{13}$. Al enterarse el emperador, es condenado al destierro en la isla de Patmos, lugar donde supuestamente escribiría el libro del Apocalipsis. De vuelta a Éfeso, tras levantarle el destierro Nerva, y para combatir las herejías, escribiría el cuarto evangelio. Es en este lugar de Asia Menor donde el sacerdote de Diana, Aristodemo, le somete a varias pruebas: la primera consistiría en destruir el templo de la diosa como muestra de la fe en su Dios. Algo que sucedió nada más comenzar a orar el apóstol. La segunda, beber un veneno de serpientes venenosas. De la misma sale victorioso. No satisfecho aún el sacerdote, Juan hubo de resucitar a los dos condenados a muerte que éste había utilizado para demostrarle a Juan que el veneno era efectivo. Finalmente, su muerte se fecha en torno al 104, siendo emperador Trajano. Existe una leyenda en la que, de forma parecida a la Virgen, fue llevado al cielo en forma de asunción: según narra la Asumptio Sancti Iohannis del Pseudo-Melitón de Sardes, el apóstol, sin haber muerto, fue arrebatado a los cielos de una fosa que él se había hecho cavar. Se tumbó en ella y cuando terminó de rezar, se inundó de luz la fosa, mientras descendía sobre el cuerpo una arena finísima que lo cubrió por entero. Las similitudes con la Asunción de María son notorias: ambos son avisados de su muerte por un ángel, y el cuerpo de los dos no es encontrado por los discípulos.

Por tanto, nos encontramos ante un personaje clave en la historia del cristianismo. Como se ha referido, y según la citada tradición, aparte de ser el autor del cuarto evangelio y del Apocalipsis, último libro de la Biblia, también habría sido el escritor de tres epístolas del Nuevo Testamento, algo que en la actualidad los escrituristas ponen en entredicho. Probablemente la autoría de todos estos libros sean ejemplos de la denominada pseudoepigrafía ${ }^{14}$.

Debido a esa importancia en la Iglesia, ostenta una variedad de patronazgos como el de teólogos, escritores, bataneros, tintoreros, armeros, aceiteros, impresores, libreros,

${ }^{2}$ Mc. 1, 19s; Mt. 4, 21.

${ }^{3}$ Mc. 3, 16; Mt. 10, 2.

${ }_{4}^{4}$ Mc. $1,29$.

${ }_{5}$ Mc. 5, 37; Mt. 17, 1.

${ }^{6}$ Mc. 9,2

7 Mc. 14, 32 .

${ }^{8}$ Mc. 9, 38; 10, 35; 13, 3.

9 Jn. 20, 2.

${ }_{10}$ Jn. 13, 23-25.

11 Jn. 19, 26s.

12 De la Vorágine, 1982: 65-70. Duchet-Suchaux/Pastoureau, 1996: 225-226. Réau, 1997: 186-199. Revilla, 2007: 330. Carmona, 2008: 232-236.

13 Ribadeneira, 1761: 37-38. Réau, 1997: 187.

14 Tuñí/Alegre, 1995. 
encuadernadores, papeleros, copistas de manuscritos, grabadores al buril o talla al dulce, viticultores o toneleros. Asimismo, se le invocaba contra las quemaduras, se le consideraba protector de las vírgenes y de las viudas, y frente a los venenos e intoxicaciones alimentarias. Finalmente, se le relaciona con las farmacias y con el patronazgo de los alquimistas ${ }^{15}$.

Dicho esto, el objeto de este artículo será el analizar el arranque de la iconografía de este santo en el entorno granadino y cómo se va extendiendo por la zona, realizando un pequeño catálogo que nos lleve a conocer algunas piezas desconocidas por la historiografía especializada, primordialmente ubicadas en localidades alejadas de la capital granadina.

\section{La iconografía de San Juan Evangelista}

Una de las iconografías hagiográficas más prolíficas y diversas quizás sea la de San Juan Evangelista. La misma está muy relacionada tanto con acontecimientos de la vida del santo narrados en los evangelios, como con leyendas aparecidas en la tradición acerca de sus milagros y hechos prodigiosos.

Dicho esto, en primer lugar, habría que establecer una primera división básica entre la forma de representar al santo en Occidente o en la cultura bizantina ${ }^{16}$. Si bien en las iglesias de tradición latina es representado como un joven imberbe y virginal, en las del mundo griego se realiza plasmándolo como un anciano con barba blanca e incluso calvo, aludiendo a la cita en la que Cristo afirma “...si quiero que él quede hasta que yo venga, ¿qué a ti? Sígueme túp'17.

A partir de ahí, tendremos que mencionar sus clásicos atributos iconográficos ${ }^{18}$ que nos permiten identificarlo con claridad: el águila, la copa de veneno, el caldero y la palma, además del libro. El primero de ellos constituye a su vez uno de los tetramorfos, procediendo de la interpretación que San Agustín hace, al comparar el evangelio de Juan con dicha ave: "Juan, en cambio, vuela como un águila sobre las nubes de la debilidad humana y contempla la luz de la verdad" ". Tanto la copa de veneno como el caldero, lógicamente hacen alusión a sendos martirios que hemos citado. Asimismo, el atributo de la palma no se refiere al martirio como lo portan otros santos que han sufrido tal suplicio. En su caso se trata de un objeto que un ángel habría entregado a la Virgen poco tiempo antes de morir, y que ésta encarga en su lecho de muerte al apóstol que porte delante de su féretro, en el funeral, con la finalidad de espantar a los demonios. Finalmente, el libro, y por extensión la pluma, aparecen como atributo por su condición de autor o escritor sagrado.

La manera de representar a San Juan es múltiple y variada, muestra de su protagonismo en los relatos evangélicos, así como su prolija leyenda en la tradición posterior. En líneas generales, se puede contemplar aisladamente en las escenas de la Santa Cena con Cristo, de la Crucifixión con María, o formando grupo con su homónimo el Bautista o con los demás apóstoles. Quizás de lo citado, lo que nos puede llamar más la atención es el emparejamiento con Juan el Bautista, ya que a priori, no existe una relación directa. La razón de su aparición conjunta reside en que se creía que la fecha de la muerte del evangelista coincidía con el aniversario del nacimiento del Bautista ${ }^{20}$.

Siguiendo los relatos evangélicos, se pueden apreciar escenas como la vocación de los hijos del Zebedeo, la citada Santa Cena, las relacionadas con la Crucifixión (sosteniendo a María desmayada, la deposición de la cruz o el llanto sobre Cristo muerto) o la Transfiguración. Dentro de los apócrifos relacionados con la Virgen, aparecería en el Tránsito, el enterramiento o Asunción.

\footnotetext{
${ }^{15}$ Réau, 1997: 188-189.

16 Réau, 1997: 189-190. Sobre este aspecto, Interián de Ayala, al analizar los errores iconográficos que se realizan en las pinturas, comenta que se suele representar joven a San Juan, pero que cuando éste sufrió martirio, tendría ya sobre noventa años, por lo que sugiere que atendiendo a esto, se le represente según las circunstancias de ambos hechos. Interián de Ayala, 1782: 195. Carmona, 2008: 234. Revilla, 2007: 330.

17 Jn. 21, 22.

18 Réau, 1997: 190. Ferrando, 1950: 154-156; Revilla, 2007: 330.

${ }^{19}$ San Agustín: Libro 1, 6, 9.

${ }^{20}$ Réau, 1997: 191.
} 
Teniendo en cuenta las leyendas vinculadas al propio santo, caben destacarse someramente los episodios que tratan acerca del martirio con el caldero de aceite hirviendo, o en la isla de Patmos, la resurrección de la drusiana en Éfeso, la conversión de cañas en oro y de piedras en gemas preciosas, el bautismo del filósofo Cratón, la prueba de la copa envenenada, la destrucción del templo de Diana, la lluvia de hostias en la tumba, la aparición póstuma de San Juan o la del milagro del anillo del rey Eduardo el Confesor ${ }^{21}$.

\section{La iconografía escultórica de San Juan Evangelista en Granada durante el naturalismo}

Tras la conquista del reino nazarí de Granada en 1492, la cristianización de este territorio se hace patente. Los Reyes Católicos plantean como una necesidad su evangelización. A partir de entonces, ese déficit de elementos artísticos medievales será compensado con la llegada de artistas foráneos que, de manera puntual, comenzarán a trabajar en la ciudad granadina. Ejemplo de ello serán Bartolomé Ordoñez, Felipe Bigarny, Jacopo Florentino o Pedro Machuca. De este modo, será como lleguen las primeras iconografías religiosas (primigeniamente en forma pictórica) y, por extensión, las primitivas imágenes de San Juan Evangelista.

Así pues, resulta lógico pensar que los primeros ejemplos iconográficos del apóstol procederían de las tablas flamencas traídas por la reina Isabel (Ej. El Tríptico de la Pasión de Dieric Bouts, El llanto de las Santas Mujeres de Hans Memling o el San Juan Evangelista en Patmos de Pedro Berruguete, todas ellas obras de finales del siglo XV) ${ }^{22}$. Asimismo sería reseñable el denominado Tríptico del Gran Capitán, donde aparece una escena de la Crucifixión, una obra atribuida a Nardon Penicaud, autor a caballo entre el siglo XV y el XVI, ubicada en el Museo de Bellas Artes de Granada, y que en su origen fue regalada por la viuda de don Gonzalo Fernández de Córdoba al Monasterio de San Jerónimo ${ }^{23}$.

En líneas generales, y exceptuando los casos que acabamos de referir, la iconografía del discípulo amado más común en el entorno granadino será la relacionada con las escenas pasionistas de la crucifixión. O bien formando parte de un Calvario junto con Cristo y la Virgen, o de forma individual, buscando dicha composición en el exorno del templo o también en uso procesional en las fechas de Semana Santa ${ }^{24}$. En este sentido cabe destacar también el trasvase de las fuentes grabadas a la escultura en cuanto a la configuración iconográfica: resulta muy similar la imagen de San Juan de este período con la que nos encontramos en algún grabado del Calvario pintado por Martin de Vos y realizado por Raphael Sadeler ${ }^{25}$. Lo que sí es reseñable es que, a pesar de representarse mayoritariamente este prototipo de iconografía, sí podemos observar en las distintas tallas los diferentes atributos iconográficos relacionados con San Juan: la copa, el libro e incluso la palma. En muchos de ellos nos aparece con el dedo señalante, indicativo de que la escultura, o en su origen estaba ubicada junto a un Crucificado, o bien en las celebraciones de la Pasión o de Semana Santa la imagen acompañaba a algún Cristo en la cruz en desfile procesional.

Centrándonos ya en la escultura, probablemente la muestra más antigua se corresponda con un relieve de los túmulos funerarios de Felipe el Hermoso y Juana la Loca, conformando grupo con San Andrés, San Miguel y San Juan Bautista, y que se ubica en la Capilla Real de

\footnotetext{
${ }^{21}$ Réau, 1997: 192-199.

22 Gallego y Burín, 1982: 246-247. Martínez Medina, 1989: 100. Bermejo, 1994: 177-213. Calvo, 1994: $215-$ 229.

23 Martínez Medina, 1989: 27.

${ }^{24}$ La iconografía del Calvario es un ciclo narrativo que sigue "un esquema compositivo en el que intervienen varios personajes, apareciendo muy rara vez uno aislado, y cuando esto sucede se debe generalmente a la adaptación a las exigencias del espacio para el que se destina". Martínez Medina, 1989: 36.

25 Bien es conocido el uso de estas fuentes por Pablo de Rojas a través de Pedro de Raxis; asimismo, Lázaro Gila establece un notable paralelismo entre el Apostolado de la Catedral de Granada de Bernabé de Gaviria con dibujos del mencionado Martin de Vos. Gila, 2010: 195-202. Muy interesante el capítulo al respecto de este tema: García, 2013: 179-256.
} 
Granada. Dicha obra fue encargada a Bartolomé Ordoñez en $1519^{26}$. Asimismo, en dicho lugar, se pueden apreciar hasta cuatro muestras de la iconografía joánica en el retablo mayor del templo ${ }^{27}$ : en el centro lo apreciamos haciendo pareja con el Bautista ${ }^{28}$; a la derecha, representando el martirio del caldero de aceite; en ese primer piso, en la primera calle de la izquierda, se observa como evangelista con sus atributos característicos; y finalmente, en el piso inmediatamente superior, conformando la escena del Calvario ${ }^{29}$. Dicho retablo sería realizado por Felipe Bigarny entre 1520 y 1522. Cabe mencionarse, asimismo, el remate de la reja de la capilla, nuevamente con un Calvario, una obra del maestro Bartolomé finalizada en $1520^{30}$. Sirva la mención de estos conocidos ejemplos como punto de arranque necesario para fundamentar nuestro trabajo. En ese primer cuarto del siglo XVI también podemos citar el conocido Santo Entierro de Jacopo Florentino, una obra que, originalmente, formaba parte del proyecto del Monasterio de San Jerónimo, panteón funerario del Gran Capitán, y que actualmente se encuentra en el Museo de Bellas Artes. Con reminiscencias tardogóticas, es reseñable la afectación, patetismo y dramatismo del discípulo amado ${ }^{31}$. En esa misma estela, aunque algo más tardíos, se encuadrarían otros tipos como los Calvarios vinculados a Diego de Aranda, ubicados en la iglesia del Sagrario ${ }^{32}$ y en la parroquial de Santa Ana $a^{33}$, ambas en la capital granadina, donde la figura del San Juan conforma la citada escena de la Pasión de Cristo. En sendos ejemplos sigue perviviendo ese recuerdo goticista, que bebe de las fuentes pictóricas flamencas, pudiendo datarse a mediados del siglo XVI. También relacionado con el citado Diego de Aranda, recientemente se ha postulado el San Juan que se encuentra en las cuevas de la Abadía del Sacromonte, fechándolo aproximadamente en torno a $1560^{34}$. Siguiendo esta estela, aunque con trazas más evolucionadas hacia el Renacimiento, destaca el San Juan que pertenecía al retablo de la iglesia de Santa Ana de la localidad granadina de Ogíares, y que hoy, encontrándose en la misma iglesia, se halla desplazado del mismo. Esta obra de Diego de Pesquera podría ser datada entre 1567-1568 ${ }^{35}$. Conforma, pues, el conjunto uno de los mayores referentes de la retablística renacentista en Granada. Algo más tarde, sobre 1580, situamos al San Juan que, procedente de la antigua iglesia de Santa Escolástica de la capital, en la actualidad se encuentra en la parroquial de San Agustín, y que tradicionalmente se ha atribuido a Cristóbal Sánchez ${ }^{36}$. Finalmente, también de las postrimerías de la centuria del XVI, hallamos el Calvario compuesto por el denominado Cristo de las Penas, la Virgen y San Juan, una obra anónima ubicada en la capilla homónima de la girola de la Catedral granadina, y de calidad artística no muy destacable ${ }^{37}$.

${ }^{26}$ Jiménez, 1846: 233. Gómez Moreno, 1892: 294. Gallego y Burín, 1982: 242. AA. VV., 2006a: 63. Cruz Cabrera, 2010: 102.

27 Jiménez, 1846: 236. Gómez Moreno, 1892: 297-298. Gallego y Burín, 1982: 242. Martínez Medina, 1989: 28-30. Martínez Medina, 1994: 97-111. Serrano, 2005: 365-385. AA. VV., 2006a: 63-64. Cruz Cabrera, 2010: 103.

28 "No olvidemos que la capilla será puesta bajo la advocación de los Santos Juanes, Bautista y Evangelista, por razones de devoción personal [de los Reyes Católicos] y en referencia a los padres de ambos monarcas". AA. VV., 2006a: 57; 63-64.

${ }^{29}$ López-Guadalupe Muñoz, 2009: 130.

30 Gallego y Burín, 1982: 240. Martínez Medina, 1989: 30-31. Martínez Justicia, 1994: 114-118. Domínguez Cubero, 2005: 333-339. AA. VV., 2006a: 61.

31 Jiménez, 1846: 261. Valladar, 1890: 310. Lo atribuye a Gaspar Becerra. Gómez Moreno, 1892: 367. Como curiosidad, mencionar que por aquel entonces, cuando aún estaba en la iglesia del Monasterio de San Jerónimo, se le atribuía a Pietro Torrigiano en torno a 1520. Gallego y Burín, 1982: 142. Martínez Medina, 1989: 102 y 127. AA. VV., 2006a: 309. López Guadalupe, 2009: 179-189. Cruz Cabrera, 2010: 106.

32 Jiménez, 1846: 243-244. Gómez Moreno, 1892: 286. Gallego y Burín, 1982: 250. Martínez Medina, 1989: 103. León Coloma, 2005: 253. AA. VV., 2006a: 52. López-Guadalupe, 2009: 133. Cruz Cabrera, 2010: 109.

33 Gómez Moreno, 1892: 409. Gallego y Burín, 1982: 338. Martínez Medina, 1989: 103 y 234. Villena/Villena, 2000: 90-92. AA. VV., 2006a: 229. López-Guadalupe, 2009: 133. Cruz Cabrera, 2010: 109. Cruz Cabrera, 2015: 230-237. 235.

34 AA. VV., 2006a: 284. En esta publicación ya se destaca la "pobre factura" de la obra. Cruz Cabrera, 2018:

35 Gómez Moreno, 1955: 289-304. AA. VV., 2006b: 339. Cruz Cabrera, 2010: 114.

${ }^{36}$ Gallego y Burín, 1982: 175. AA. VV., 2006a: 180.

37 Martínez Medina, 1989: 104. López-Guadalupe, 2005: 495-496. 
La escuela granadina de escultura, propiamente dicha, comenzará su andadura en el último tercio del siglo XVI con la figura del escultor de Alcalá la Real (Jaén), Pablo de Rojas (1549†1611). El que fuera maestro de Martínez Montañés, elaborará una gran variedad de prototipos iconográficos, perpetuándose en el tiempo a través de varios de sus discípulos, como por ejemplo Bernabé de Gaviria o ya en las postrimerías, Alonso de Mena. Uno de estos modelos será el de San Juan Evangelista. Quizás el primer prototipo que realiza de esta imagen sea el de la parroquial de la localidad de Las Gabias [Fig. 1], un ejemplo en el que destaca la elegancia y la belleza clasicista, así como la rotundidad en sus formas. En el rostro se vislumbra el semblante romanista del comienzo de su obra, ejecutado de perfil, una herencia proveniente de los tipos realizados por Diego de Pesquera ${ }^{38}$. Asimismo, aúna la tipología de paños del segundo tercio del siglo XVI. Resulta curioso el pliegue del brazo izquierdo que se oculta debajo del brazo, tensando el tejido desde el hombro hacia la extremidad. Este detalle es apreciable también en imágenes como el San Juan de la iglesia de San Francisco de Priego de Córdoba (Córdoba) o la Dolorosa del Calvario del retablo mayor de Albolote.

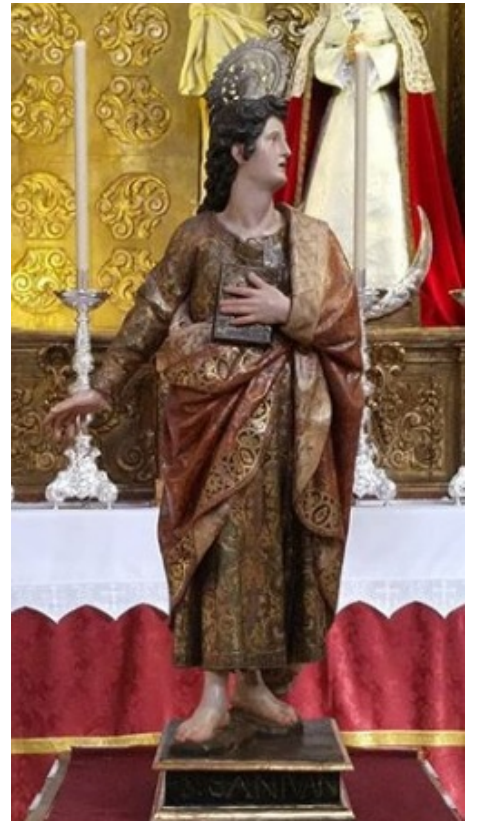

Fig. 1. San Juan Evangelista, atrib. Pablo de Rojas, finales del siglo XVI. Iglesia parroquial de La Encarnación, Las Gabias (Granada). Foto: José Antonio Peinado Guzmán [JAPG].

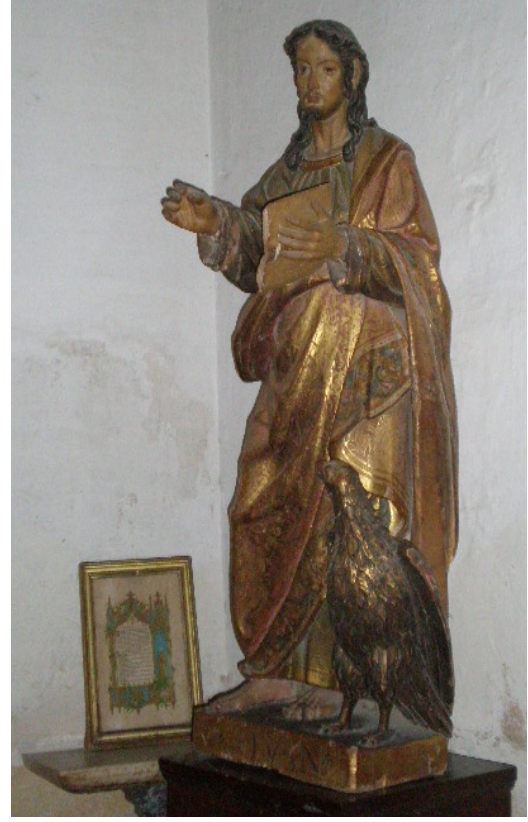

Fig. 2. San Juan Evangelista, Pablo de Rojas, 1588-1589. Catedral de Granada. Foto: JAPG.

Pero quizás la pieza de esta tipología más determinante sea el ejemplo de la Catedral de Granada ${ }^{39}$. Ubicado sobre las cajoneras de la sacristía de la sede granadina, utiliza el modelo que hace genérico para las imágenes de apóstoles, añadiéndole los atributos típicos de San Juan: el libro en su mano izquierda y el águila a sus pies, amén de su rostro imberbe que nos da muestra de su juventud. El clasicismo de sus formas y su plegado característico hacen

${ }^{38}$ López-Guadalupe, 2010a: 148-150.

${ }^{39}$ Gallego y Burín, 1982: 269. En época de Gallego y Burín estaba colocado en una hornacina de la girola catedralicia. León Coloma, 2005: 257. AA. VV., 2006a: 37. Cabe mencionarse que esta imagen, cuando fue editada esta publicación, estaba ubicada en la Capilla de San Sebastián de la sede catedralicia. López-Guadalupe, 2010a: 146. Esta imagen, junto con las de San Esteban, San Cecilio y San Gregorio, pertenecían al antiguo retablo de la Virgen de la Antigua, arriba citado. 
plausible la tradicional atribución de esta talla al escultor alcalaíno. La imagen es fechada entre 1588-1589, cuando se realiza el antiguo retablo de la Virgen de la Antigua, donde estaba ubicada en su origen [Fig. 2]. No debemos olvidar otros ejemplos vinculados a la obra de Rojas, también muy conocidos, como el San Juan que conforma tanto el retablo mayor de la iglesia del Monasterio de San Jerónimo ${ }^{40}$, como el del templo del convento de Santa Isabel la Real ${ }^{41}$. Igualmente, también es conocido el que se haya en la capilla del Cristo de Burgos de la Basílica de la Virgen de las Angustias ${ }^{42}$.

Es en este período cuando acontece un suceso enormemente trascendental para la historia de la incipiente Granada cristiana. Nos referimos a la Guerra de las Alpujarras (1568-1571). Dicha rebelión, no sólo se circunscribió a esa comarca granadina, sino que se extendió a más lugares (Costa, Vega o territorios de la zona norte muy cercanos a la capital). Independientemente de lo cruenta de la misma, y de las consecuencias posteriores que tuvo para la población morisca de la zona, desde el punto de vista que nos interesa hemos de reseñar ciertos cambios. En primer lugar, será necesario restituir todo el patrimonio perdido a consecuencia del conflicto bélico. Se levantarán nuevos templos y se exornarán con sus consiguientes imágenes. Y, en segundo lugar, se variará la estrategia pastoral realizada hasta ahora: esa tendencia a retener la producción imaginera por respeto a la población morisca hasta ese momento, quedará absolutamente cancelada tras la guerra. Ya no habrá más miramientos al respecto, y el uso de la imagen se impondrá en el proceso evangelizador ${ }^{43}$. Hasta ahora nos hemos ceñido a la capital granadina, a partir de este momento, tendremos que mirar a las numerosas localidades que se surtirán de tallas, puesto que, hasta esas fechas, muchas de ellas se nutrían de simples sargas o guadamecíes pintados que suplían la carencia de esculturas. Esto seguirá perpetuándose incluso entrado el siglo XVII, puesto que contemplaremos ejemplos de ello en diferentes pueblos del antiguo reino nazari ${ }^{44}$.

Es en este doble proceso de cristianización y de reconstrucción de templos de finales del siglo XVI y principios del siglo XVII, donde la iconografía que estamos tratando alcanza una importante dimensión en los municipios alejados de Granada. Y es que la imagen de un sencillo Calvario va a ser esencial en la labor evangelizadora del clero, ya que, de forma sintética, se expresaban así los misterios de la fe cristiana. No en vano, San Juan de Ávila ya aconsejaba a don Pedro Guerrero, arzobispo del lugar entre 1546 y 1576, tras la Guerra de las Alpujarras, que el instrumento más adecuado para propagar la doctrina era la imagen de Cristo crucificado, sobre todo la escena del Calvario en la que se acompaña de la Madre y el discípulo amado, encarnación misma de la Iglesia y del testimonio evangélico: "Bien sería que llevasen [los misioneros]... algunas imágenes del Santo Crucifijo y de Nuestra Señora y San Juan, para que los predicadores las diesen a los pobres de los pueblos, para que recen, poniéndoles algunas imágenes en sus casas" ${ }^{\prime 45}$. Posteriormente al citado conflicto bélico, está atestiguado documentalmente el retablo de la parroquial de Albolote (Granada), una obra en

40 Valladar, 1890: 309. Gómez Moreno, 1892: 369-372. Gallego y Burín, 1982: 293. Martínez Medina, 1989: 108. AA. VV., 2006a: 158. López-Guadalupe, 2010a: 145. Hemos de referir que en dicho retablo hay dos imágenes de San Juan: una en el Calvario y otra entre las columnas, pareado con un Bautista.

41 Jiménez, 1846: 383. Gómez Moreno, 1892: 444. Gallego y Burín, 1982: 382. Martínez Medina, 1989: 108. Gómez-Moreno Calera, 2002: 9-32. AA. VV., 2006a: 253. En este artículo se relaciona tanto con Pablo de Rojas como con Bernabé de Gaviria, su discípulo. López-Guadalupe, 2010a: 156. Se completaría la bibliografía sobre los retablos con: Gómez-Moreno Calera, 2010: 239-272.

42 Gómez Moreno, 1892: 237. Gallego y Burín, 1982: 193. AA. VV., 2006a: 118.

43 "Las diferentes estrategias desarrolladas desde el arzobispo Talavera al Cardenal Cisneros en relación al problema morisco forman parte del mismo proceso que retiene la producción de imágenes, producción que queda como liberada tras la sublevación de las Alpujarras". López-Guadalupe, 2010a: 139.

44 Ejemplo de ello lo encontramos en Cogollos Vega (Granada) con unas pinturas de Pedro Rodríguez. Archivo Histórico Diocesano de Granada [AHDGr], Legajo 329-F, pieza 3, Libro de Contaduría Mayor de 1582. Otros ejemplos similares en un guadamecí los hallamos en Dalías (Almería): Legajo 330-F, pieza 2, Libro de Contaduría Mayor de 1600; Yegen (Granada): Legajo 333-F, pieza 3, Libro de Contaduría Mayor de 1609 o uno en Dúrcal (Granada), procedente de las escaleras de las casas arzobispales: Legajo 336-F, pieza 1, Libro de Contaduría Mayor de 1614.

45 López-Guadalupe, 2010b: 62. 
mancomún entre Pablo de Rojas y Bernabé de Gaviria encargada a finales de $1606^{46}$. En publicaciones más recientes, puesto que no se especifica qué hizo cada uno, el prof. Lázaro Gila sostiene que el Calvario que remata el citado retablo pudiera haber sido realizado por Gaviria ${ }^{47}$. Fuere como fuere, lo cierto es que la estela de Pablo de Rojas, como vamos a ir viendo, se va a perpetuar en los diferentes modelos iconográficos en sus discípulos (ej. Bernabé de Gaviria, Martín de Aranda o Alonso de Mena ya en las postrimerías de influjo).

El discípulo más cercano, pues, será Bernabé de Gaviria (1577-†1622). Tal es así que se cree que incluso heredó el taller del maestro ${ }^{48}$. La obra más importante de Gaviria será el Apostolado de la Catedral de Granada ${ }^{49}$, donde realizará diez de los doce apóstoles. Dicho trabajo se realizaría en dos fases, entre 1611 y 1617. La imagen de San Juan, que es la que nos interesa, sigue siendo muy cercana a la que Rojas había hecho dos décadas antes para el retablo de la Virgen de la Antigua del templo catedralicio.

En este sentido, consideramos que otras esculturas joánicas relacionadas con sus gubias serían la que se halla en el templo parroquial de la localidad granadina de La Zubia [Fig. 3]. La misma, que por la pose intuimos que debió componer la escena de un Calvario o al menos de servir para el acompañamiento procesional de alguna escena pasionista, en la actualidad se encuentra exenta en una repisa del lado de la epístola de la iglesia. Viste túnica verde y manto rojo terciado de izquierda a derecha. Aunque el color de la túnica no sea el clásico que se apunta en la tratadística ${ }^{50}$, quizás venga a evocar el tema de la esperanza al ser considerado el autor del Apocalipsis, libro que trata acerca de la vida tras la muerte, así como una alusión a la redención, pues el color verde también se ha relacionado con el "árbol de la cruz" 51 . Curiosamente, esa tonalidad se hace genérica en la totalidad de ejemplos que planteamos en este trabajo. Con la mano izquierda sujeta junto a su regazo uno de sus atributos clásicos, el libro, como escritor sagrado que es; su brazo derecho se alza,

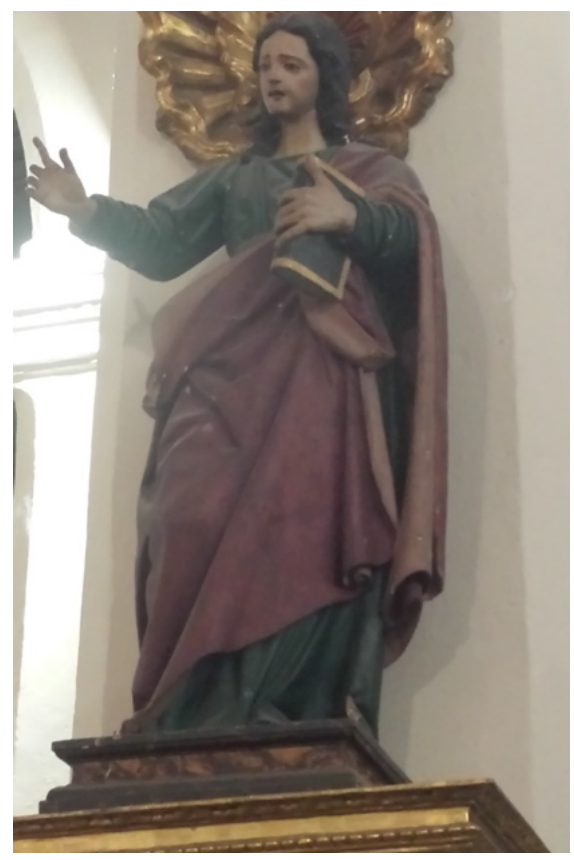

Fig. 3. San Juan Evangelista, atrib. Bernabé de Gaviria, primer cuarto del siglo XVII. Iglesia parroquial de Nuestra Señora de la Asunción, La Zubia (Granada). Foto: JAPG.

46 Martínez Medina, 1989: 108. Gómez-Moreno Calera, 1993: 37-41. AA. VV. Guía artística de Granada y su provincia (II). Sevilla: Fundación José Manuel Lara, 2006, p. 351. En esta publicación únicamente se cita en cuanto a la autoría a Pablo de Rojas y a Martín de Aranda. López-Guadalupe, 2010a: 145 y 148.

47 Gila, 2010: 191-192. En este sentido se basa en ciertas apreciaciones en el modelado de la talla como son el pliegue oval sobre la rodilla derecha, o el abundante plegado en continuas circunferencias de los brazos de algunas imágenes, que vendrían a suponer un rasgo característico de sus gubias.

48 Gila, 2010: 185 y 195.

49 Jiménez, 1846: 194-195. Valladar, 1890: 298. Gómez Moreno, 1892: 265. En esta publicación aún se las atribuye a Martín de Aranda y a Alonso de Mena erróneamente. Sánchez-Mesa, 2005: 414. Ya la atribuye a Bernabé de Gaviria bajo la dirección de Pablo de Rojas. León Coloma, 2005: 270. AA. VV., $2006 a: 26$. Curiosamente, en esta publicación tan reciente se las vincula con Gaspar de Aranda (evidentemente es un error, pues probablemente se referiría a Martín) y Alonso de Mena. Gila, 2010: 199.

${ }^{50}$ Hemos de reseñar que hay autores que consideran que los colores de la iconografía de San Juan deberían ser la "túnica azul o blanca, símbolo de su pureza y virginidad; y el manto rojo porque, aunque no murió víctima de ningún tormento, «no faltó el ánimo al martirio, sino el martirio al ánimo de San Juan»", Carmona, 2008: 234.

${ }^{51} \mathrm{El}$ color verde en el cristianismo es un color que se halla a la misma distancia del "azul del cielo que del rojo del infierno... un color intermedio y mediador, tranquilizante, refrescante, humano [...] el color del recogimiento, de la esperanza de la resurrección [...] color verde como símbolo de esperanza en la redención". En: Biedermann, 1989: 476. Junto con el tradicional simbolismo de la esperanza, tiene un carácter redentor, no en vano en la Edad Media a la cruz de Cristo se la pintaba de verde, instrumento de la regeneración del género humano. En: Chevalier / Gheerbrant, 1986: 1057-1060. 
señalando con su dedo índice, entendemos que en su origen a algún Cristo crucificado. Hay una serie de rasgos que nos llevan a vincular esta imagen con Gaviria. En líneas generales, los rasgos más duros en la factura y trabajo de la gubia, son relacionados con Bernabé, tradicionalmente, en contraposición a la blandura y delicadeza más idealizada de su maestro Rojas ${ }^{52}$. En la imagen se percibe, pues, cierta rotundidad de formas que ensalza un realismo más acuciado (pliegues cortantes, rostro afilado, dedos rígidos con nudillos muy marcados, casi más como un trabajo pétreo que lignario). Otros rasgos que, últimamente, se han asociado con la estética de Gaviria son la configuración del entrecejo de la talla, con cejas notoriamente inclinadas, diferenciándose de la forma paralela respecto al ojo, que Rojas tendía a elaborar en sus hechuras. Igualmente, a modo de detalle característico, entre ambas cejas suele apreciarse una leve hendidura, como si de un mínimo golpe de gubia se tratase, que en muchas de sus imágenes se aprecia ${ }^{53}$. De igual modo, tanto el plegado de las mangas de la túnica, desarrollando varios anillos sucesivos, como el modelado del cabello a base de pequeños mechones paralelos, son otros mínimos rasgos que nos ayudan a establecer una vinculación de esta talla con el trabajo de este escultor ${ }^{54}$. Siguiendo esa estela situaríamos dos imágenes más de San Juan. Una de ellas es la que se ubica en la iglesia del capitalino Convento de Santa Catalina de Siena [Fig. 4] ${ }^{55}$. La misma reitera la policromía anteriormente citada. Como atributos iconográficos aparecen la copa y el águila. La escultura ofrece algunos de los grafismos mencionados que se relacionan con Gaviria como la forma tan peculiar de trabajar las mangas de la túnica, los rasgos faciales más duros con respecto al maestro o los dedos con nudillos y tendones muy marcados. A esto habría que añadir el plegado oval sobre la rodilla adelantada, otro detalle que se vincularía a su factura ${ }^{56}$. Si bien esta imagen ha sido tradicionalmente relacionada con Pablo de Rojas, por las razones aducidas, proponemos la atribución a su discípulo Bernabé de Gaviria. La otra imagen que comentábamos sería la que se halla en la iglesia parroquial de la localidad de Melegís [Fig. 5]. A diferencia de la del Convento de Santa Catalina, mucho más afecta al modelo de San Juan establecido por Rojas en la Catedral granadina, esta, aun apreciándose similitudes, ofrece otro registro. Como detalle, comentar que intuimos que el atributo iconográfico que portaba

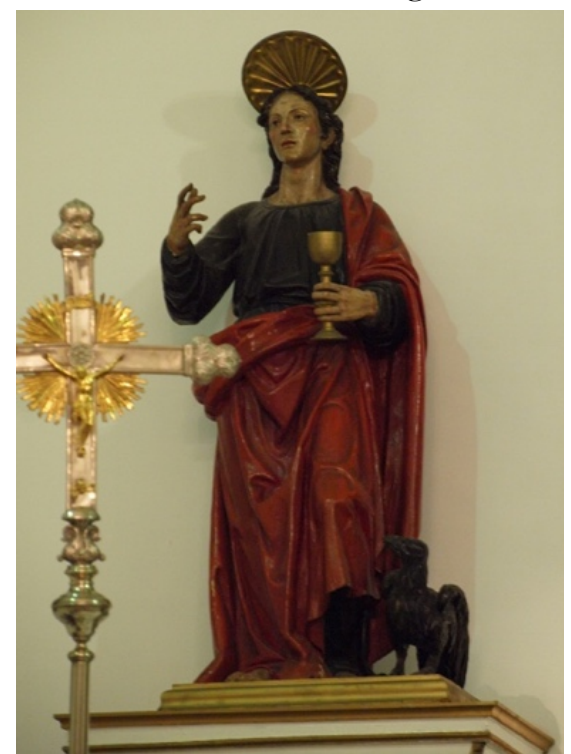

Fig. 4. San Juan Evangelista, atrib. Bernabé de Gaviria, primer cuarto del siglo XVII. Iglesia del Convento de Santa Catalina de Siena, Granada. Foto: JAPG.

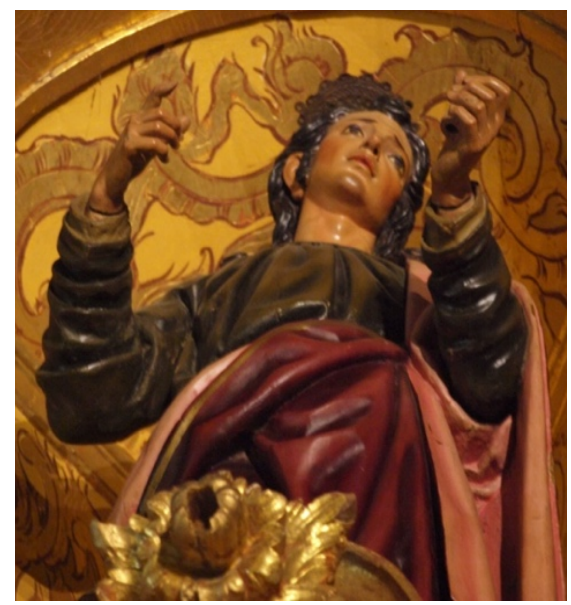

Fig. 5. San Juan Evangelista, atrib. Bernabé de Gaviria, primer cuarto del siglo XVII. Iglesia parroquial de San Juan Bautista, Melegís (Granada). Foto: JAPG.

\footnotetext{
52 En este sentido, cabe referirse que el sentido de esta aseveración no significa que las imágenes de Gaviria sean de menor calidad que las de Rojas. Compartimos con el prof. Gila Medina la idea de rechazar que "lo bueno o mejor logrado en cualquier trabajo sería obra del maestro, mientras que aquellas otras partes menos conseguidas habría que incluirlas en el haber del sobrino-discípulo". Gila, 2010: 186.

53 León Coloma, 2010: 616-617.

54 Gila, 2010: 192 y 206.

55 Gallego y Burín, 1982: 169. AA. VV., 2006a: 213.

56 Gila, 2010: 192.
} 
era una copa, de la que solo se conserva en la actualidad el nudo de la misma. De infinita menor calidad a los referidos, citamos también el de la localidad alpujarreña de Cáñar [Fig. 6], enormemente deteriorado. Se observa una imagen en sí bastante tosca, de taller, y que vinculamos con Gaviria, además de por ciertos estilemas muy difuminados que se aprecian, porque este escultor realizó para esta localidad una Virgen del Rosario en $1612^{57}$. Teniendo en cuenta que esta imagen suponía un elemento más dentro de la reconstrucción de la imaginería en dicha zona tras el levantamiento de las Alpujarras, no sería descabellado pensar que esta talla fuese encargada también, a modo de lote, al propio Bernabé de Gaviria. De los discípulos menos conocidos de Rojas se ha de reseñar, junto a Diego de Navas, a Martín de Aranda, que es citado en la participación del retablo mayor de iglesia de Albolote (Granada) ${ }^{58}$. De su obra sabemos muy poco. Tradicionalmente se le atribuye el San Juan Evangelista del templo de Nigüelas (Granada) ${ }^{59}$. La misma es una talla aún muy deudora del canon que estableció Rojas con la imagen joánica de la antigua capilla de la Virgen de la Antigua, aunque se percibe cierta evolución en el rostro, que barrunta los nuevos modelos que impondrá Alonso de Mena. Es fechada en torno a 1643. Relacionada con esta imagen estaría también la imagen de San Juan del municipio alpujarreño de Lanjarón. En la misma se observa un gran parecido en el rostro, así como en la forma de tallarla, casi pétrea. De este modo, si la de Nigüelas es tradicionalmente atribuida a Martín de Aranda, podemos mantener esta misma atribución para la escultura lanjaronense.

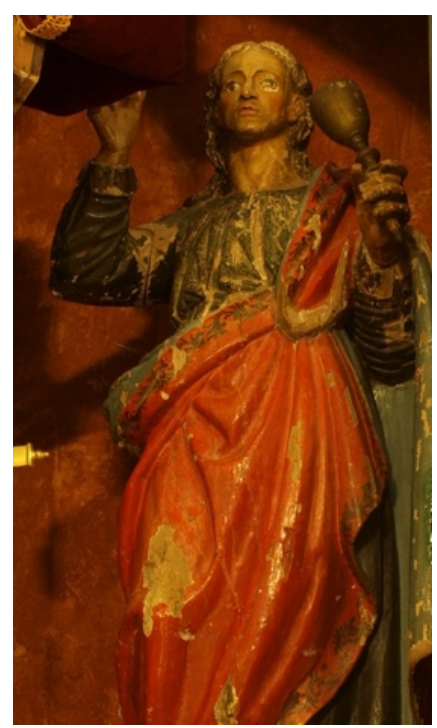

Fig. 6. San Juan Evangelista, atrib. Bernabé de Gaviria (taller), primer cuarto del siglo XVII. Iglesia parroquial de Santa Ana, Cáñar (Granada). Foto: JAPG.

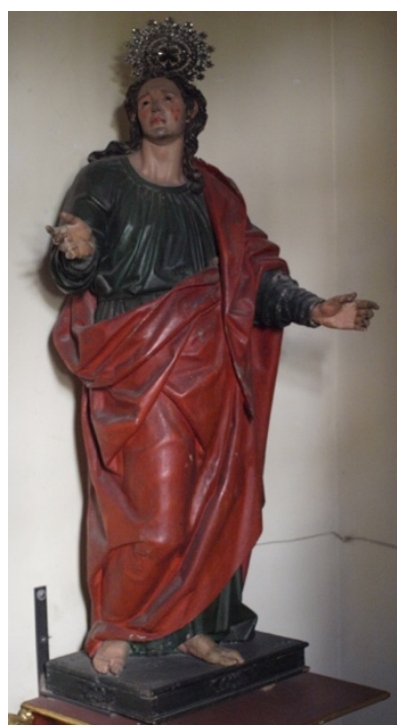

Fig. 7. San Juan Evangelista, atrib. Alonso de Mena, c. 1613. Convento del Santo Ángel Custodio (dependencias interiores), Granada. Foto: JAPG.

Sin lugar a dudas, el discípulo de mayor envergadura de Pablo de Rojas será Alonso de Mena (1587-†1646). Algo más alejado en el tiempo que los anteriores, perpetúa las esencias del maestro hasta ir configurando un estilo marcadamente propio. Su obra, tremendamente prolífica, va a estar marcada por la ausencia de otros escultores (una vez

\footnotetext{
${ }^{57}$ López-Guadalupe, 2006: 164.

58 Gómez-Moreno Calera, 2010: 260.

${ }^{59}$ Gómez-Moreno Calera, 1997: 54. AA. VV., 2006b: 313. En esta publicación la atribuye a Pablo de Rojas o a Bernabé de Gaviria. Palomino / Rodríguez, 2013: 48. Según parece, en un inventario parroquial de 1643 ya aparece citada esta imagen, de ahí la fecha de datación aproximada que se ofrece.
} 
desaparecidos tanto Rojas como Gaviria) ${ }^{60}$, y por la gran cantidad de encargos a los que tuvo que hacer frente en su taller (no olvidemos, por ejemplo, la necesidad de exorno en las iglesias arrasadas tras la Guerra de las Alpujarras). Del mismo no sólo salían trabajos de escultura, sino también retablos, yeserías, barros, plomos, portadas... Y curiosamente, y a pesar de no tener competencia, a precios muy asequibles. Ya sea porque tenía que mantener a una extensa prole, o por sostener la actividad constante en el taller, o porque por su profunda personalidad no le movía el interés económico, lo cierto es que sus precios eran bastante módicos ${ }^{61}$. Entrando ya en materia con la iconografía de San Juan, el primero que relacionamos con las gubias de Mena es el que se haya en la clausura del Convento del Santo Ángel Custodio de la capital granadina [Fig. 7]. Originariamente la escultura procedía de la iglesia de San Cristóbal. La talla, tradicionalmente ha sido atribuida a Pablo de Rojas ${ }^{62}$. Ciertamente la imagen se muestra aún muy afecta a los cánones "rojanos". Será el prof. Juan Jesús López-Guadalupe quien comience a catalogarla como muy cercana a Alonso de Mena ${ }^{63}$. Aún bebe del modelo catedralicio ideado por el maestro, donde tanto en el plegado del manto como en el modelado del cabello (evoca al realizado en modelos femeninos tales como la Virgen de los Favores del templo de San Juan de los Reyes o el Cristo de Paciencia y Penas de la parroquial de San Matías, por ejemplo). Se va apreciando su estilo en detalles como un mayor realismo en su rostro, o la caída del pico del manto por el pecho muy característica de sus composiciones. Por tanto, podríamos encontrarnos ante una imagexn del primer período de su etapa artística, hasta 1613, etapa de formación y aprendizaje ${ }^{64}$. De esta misma época podríamos situar también el San Juan de la parroquia de la localidad de Albuñuelas [Fig. 8]. Similitudes tanto en el plegado, en el rostro e incluso en la disposición del cabello, aunque con una ejecución de menor finura, nos hacen vincular esta talla a este primer Mena.

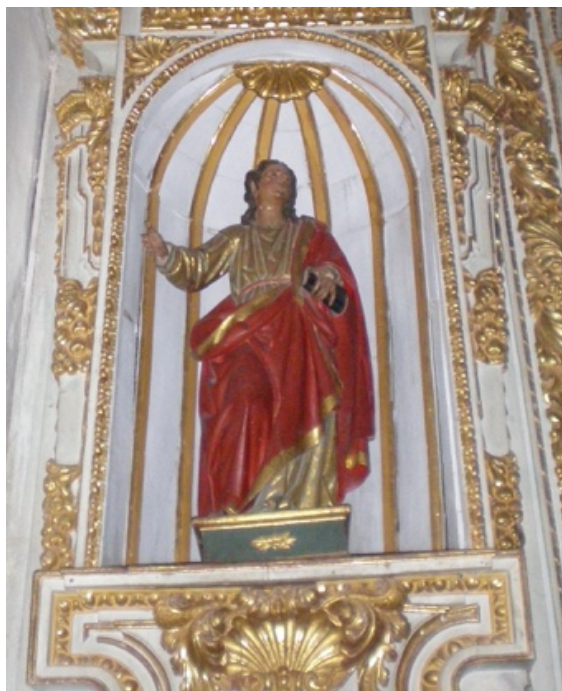

Fig. 8. San Juan Evangelista, atrib. Alonso de Mena, c. 1613. Iglesia parroquial de El Salvador, Albuñuelas (Granada).

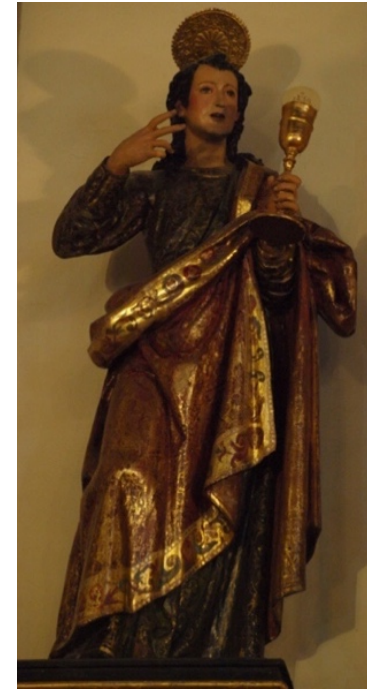

Fig. 9. San Juan Evangelista atrib. Alonso de Mena, c. 1613-1629. Iglesia parroquial de La Inmaculada Concepción, Dílar (Granada).

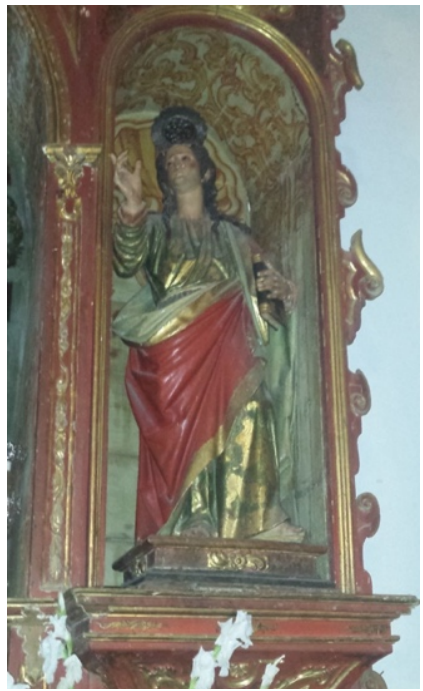

ig. 10. San Juan Evangelista, atrib. Alonso de Mena, c. 1620. Iglesia parroquial de $\mathrm{La}$ Visitación de Nuestra Señora, Churriana de la Vega (Granada).

${ }^{60}$ No debemos olvidar a los hermanos García, Miguel Jerónimo y Jerónimo Francisco, coetáneos a Alonso de Mena, pero de menor impacto en cuanto a su producción artística. Quizá ello se deba a su status eclesiástico, además de su pertenencia a una élite social (algo que hacía despreciar el trabajo manual), por lo que su actividad imaginera probablemente no fue profesional. López-Guadalupe, 2010c: 212.

61 Gila, 2013: 27.

62 Gallego y Burín, 1982: 374. Martínez Medina, 1989: 108. AA. VV., 2006: 89.

${ }^{63}$ López-Guadalupe, 2009: 151.

${ }^{64}$ Gila, 2013: 22-25. 
Con alguna variante estética, como el movimiento del brazo derecho, o la sujeción de la copa en lugar del libro, hallamos en la iglesia del municipio de Dílar [Fig. 9] otra muestra interesante $^{65}$. La policromía y su estofado son magníficos, siendo su rostro de enorme parecido al del San Miguel de la iglesia de Pórtugos, una imagen atribuida a Mena en torno a $1622^{66}$. No olvidemos que en este templo encontramos una escultura también de San Francisco, igualmente vinculada a este escultor, aunque quizás algo más tardía ${ }^{67}$. Por tanto, nos vamos adentrando en el período de consolidación, que durará aproximadamente hasta $1629^{68}$. Es en torno a 1620 cuando ya datábamos en otro artículo el San Juan de la localidad de Churriana de la Vega [Fig. 10] ${ }^{69}$. Probablemente con repintes posteriores, se percibe un tratamiento del pelo interesante, con dos finas guedejas onduladas que caen sobre el pecho; el característico pico del manto ya citado también aparece aquí, como otro rasgo típico de su obra, que es doblar hacia atrás las mangas de la túnica en muchas de sus imágenes. Esta talla del municipio de la Vega granadina, habríamos de ponerla en relación con otra, sobradamente conocida, que se ubica en la parroquial capitalina de San Pedro y San Pablo ${ }^{70}$. En dicho San Juan, tradicionalmente atribuido a Pablo de Rojas, nosotros creemos ver la mano de un Alonso de Mena algo más evolucionado, pero con resabios aún de su maestro. Hay un detalle, casi imperceptible, que nos hace asociar esta escultura con la obra de dicho escultor: en la caída del manto, la finalización del pliegue encorbatado sobre su rodilla izquierda, la ejecuta realizando una especie de plisado a modo de espiral, que se ve con mucha asiduidad en los perizomas de sus crucificados, y que su maestro Rojas no hacía. En esta etapa podríamos situar también una bella talla de San Juan del municipio de Maracena, con notables similitudes con la citada de Churriana de la Vega, y de buena calidad artística. De su etapa de plenitud ${ }^{71}$, dejamos tres joyas escultóricas prácticamente desconocidas por la crítica o que, directamente, se ha pasado por ellas "de puntillas". Nos referimos a las imágenes de San Juan de Béznar ${ }^{72}$, Alfacar y Cúllar Vega ${ }^{73}$ [Figs. 11, 12 y 13], todas ellas en un entorno más o menos próximo a la capital granadina. Los dos primeros ejemplos mencionados mantienen ciertas similitudes.

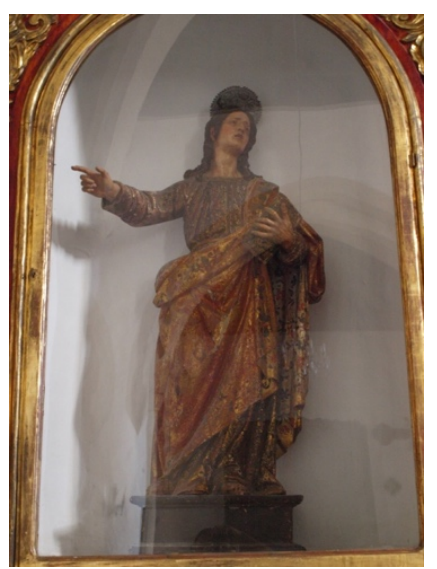

Fig. 11. San Juan Evangelista, atrib. Alonso de Mena, c. 1629-1646. Iglesia parroquial de San Antón, Béznar (Granada).

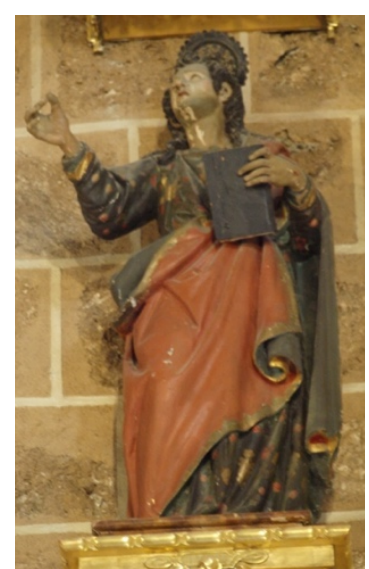

Fig. 12. San Juan Evangelista, atrib. Alonso de Mena, c. 1629 1646. Iglesia parroquial de Nuestra Señora de la Asunción, Alfacar (Granada).

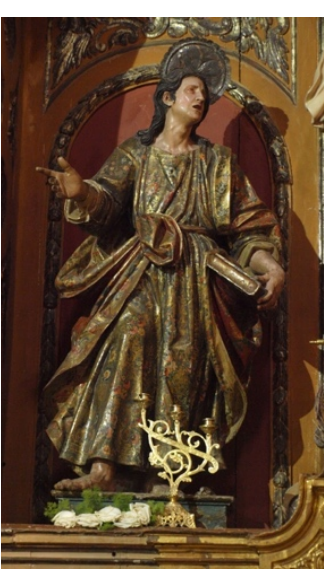

Fig. 13. San Juan Evangelista, atrib. Alonso de Mena, c. 1629-1646. Iglesia parroquial de Nuestra Señora de la Asunción, Cúllar Vega (Granada).

\footnotetext{
65 AA. VV., 2006: 324.

${ }^{66}$ Gila, 2013: 71.

67 Gila, 2013: 70.

${ }^{68}$ Gila, 2013: 25-34.

69 Peinado Guzmán, 2016: 74-75.

${ }^{70}$ Gallego y Burín, 1982: 350. López-Guadalupe, 2010: 148. AA. VV., 2006: 236. Gila, 2013: 53.

71 Gila, 2013: 34-50.

72 AA. VV., 2006b: 309. Relaciona la imagen con el estilo de Bernabé de Gaviria.

73 AA. VV., 2006b: 354. Simplemente la cita.
} 
La disposición de la vestimenta perpetúa el modelo "rojano" ya consagrado. Si bien la policromía de la muestra de Béznar, probablemente retocada en el siglo XVIII, necesitaría alguna intervención de restauración, rezuma el gusto de su calidad tanto en la estofa como en los motivos vegetales variopintos que esboza. Por el contrario, en el ejemplo de Alfacar, en lo referente al manto y la túnica, la labor polícroma es mucho más plana, con seguridad también intervenida con el paso del tiempo. Donde sí se perciben notables semejanzas es en el rostro de ambos: facciones faciales de corte cuadrangular, boca tendente hacia abajo mostrándonos el sufrimiento del apóstol, así como las cejas inclinadas. Nos evoca claramente a la talla del San Sebastián de la localidad alpujarreña de Bayacas, que en su momento también relacionamos con las gubias de Alonso de Mena ${ }^{74}$.

La imagen que ofrece una mayor originalidad, sin lugar a dudas, es la de la localidad de Cúllar Vega. Tanto el realismo acuciante que nos muestra el rostro, como la diferente disposición de los plegados, nos permiten observar un modelo distinto y novedoso de la iconografía joánica a lo que hemos visto hasta ahora. Especialmente en esto último que reseñamos: unos plisados ampulosos, con un volumen tal, que confieren a la pieza una morfología cuasi oval. Como detalle se ha de referir cómo el manto se recoge bajo el cíngulo de la túnica, cayendo con un vistoso pliegue en forma de rosa. Estas formas creemos que ya había comenzado a experimentarlas en las puertas del armario relicario del lado del evangelio de la Capilla Real de Granada, concretamente en la imagen de San Pedro, en torno a 1630. De ahí que consideremos, puesto que en esta imagen observamos los pliegues más evolucionados y perfeccionados, que la talla de San Juan pertenezca a su última etapa artística.

Finalmente, hemos de hacer alusión a otras imágenes, de bastante menor calidad, que consideramos que forman parte de ese elenco de esculturas de taller, de factura más tosca, pero que vienen a cubrir sobradamente su función cultual para lo que fueron concebidas. Nos referimos a las tallas de San Juan de las localidades de Ogijares [Fig. 14] ${ }^{75}$, en la iglesia de Santa María de la Cabeza, y la del templo parroquial de Órgiva [Fig. 15].

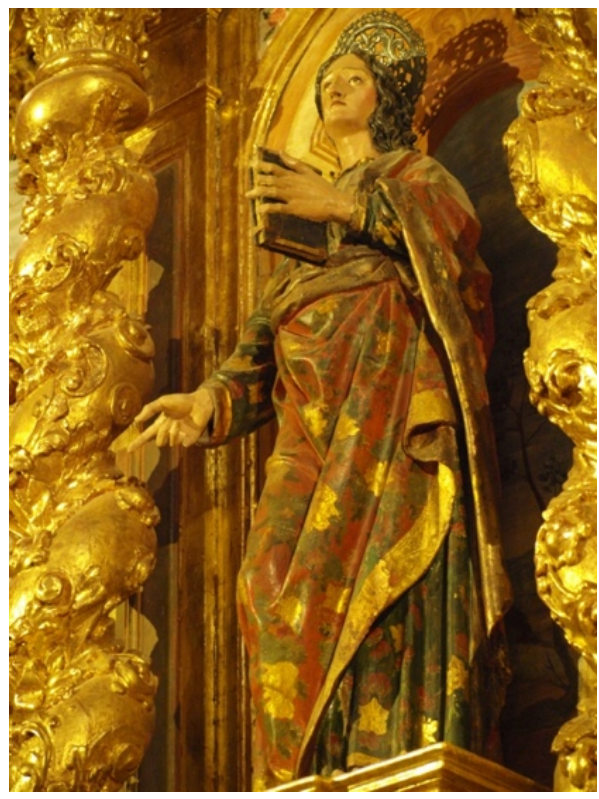

Fig. 14. San Juan Evangelista, atrib. Taller de Alonso de Mena, primera mitad del siglo XVII. Iglesia de Santa María de la Cabeza, Ogijares (Granada).

\footnotetext{
74 Peinado Guzmán / Palomino, 2017: 270-272.

75AA. VV., 2006b: 338.
}

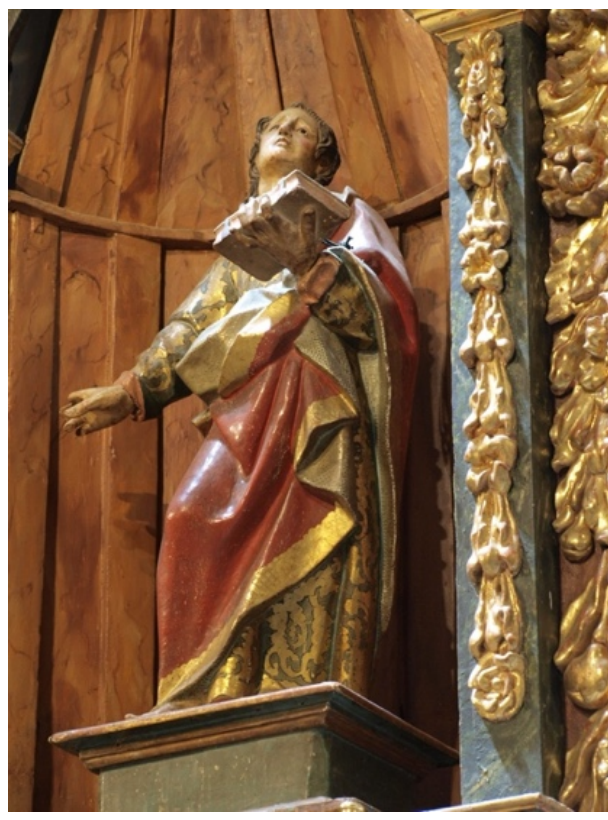

Fig. 15. San Juan Evangelista, atrib. Taller de Alonso de Mena, primera mitad del siglo XVII. Iglesia parroquial de Nuestra Señora de la Expectación, Órgiva (Granada). 


\section{Conclusiones}

Una vez realizado este periplo por la iconografía de San Juan en el entorno granadino, podemos sacar una serie de conclusiones interesantes al respecto. La primera de ellas es obvia por su reiterada repetición: el modelo iconográfico casi exclusivo es el del Calvario. A excepción de las representaciones del retablo mayor de la Capilla Real (como evangelista, acompañando al Bautista o en el suplicio de la tinaja de aceite hirviendo), el resto conforman el tipo de la escena al pie de la cruz. Una de las razones que puede estar relacionada con esta ausencia de modelos joánicos diversos puede ser la no existencia de una Edad Media cristiana en Granada. Algunos de estos prototipos que repasábamos en la primera parte de este artículo fueron muy prolíficos en el medievo, al albur de las leyendas y supersticiones propias de dicho período. Ejemplo de ello es la famosa Leyenda Dorada, compilada a mediados del siglo XIII. La Granada post-musulmana vivirá un contexto completamente distinto y en una época diferente, puesto que se reincorpora al cristianismo ya en el Renacimiento, con todo lo que ello implica. Consecuencia de ello, viene a colación otra conclusión: la funcionalidad de la imagen. La repetición del modelo, como se ha esbozado en este trabajo, tiene una finalidad catequética y evangelizadora. La necesidad de convertir a aquellas gentes, fuertemente arraigadas en su fe mahometana, necesitaba de un discurso nuclear, relato que se concentraba en el misterio de la crucifixión. Mediante la sencilla imagen de un Calvario, se aglutinaba y se resumía la esencia de la fe cristiana. Por esta razón, las imágenes de San Juan venían a acompasar a la perfección esa función de catequesis. Curiosamente, la proliferación de este modelo de esculturas coincide también con el período posterior a la Guerra de las Alpujarras. Casa, pues, el aumento de esta producción imaginera con esas necesidades, tanto de evangelización, como de restitución de templos y sus enseres tras el conflicto bélico. Por tanto, la época del denominado naturalismo escultórico será el período donde acontezca todo lo referido. De hecho, una vez completada esa carencia o exigencia, esto es, la sociedad granadina estaba plenamente cristianizada y los templos, o bien ya tenían su respectiva imagen de San Juan o Calvario, o las necesidades religiosas pedían ya otro tipo de iconografías, la proliferación o generación descienden notablemente.

Para concluir, aunque se salga de la etapa que estamos trabajando, y por completar el elenco, citaremos otras imágenes de San Juan que hemos hallado en nuestro extenso trabajo de campo, tales como la que se encuentra en la iglesia del Convento de las Carmelitas de la Antigua Observancia de la capital ${ }^{76}$, de escaso valor artístico; o en localidades tan diversas como La Malahá o Huétor Santillán, con dos tallas relacionadas con la obra de Pedro de Mena; Padul o Güéjar Sierra ${ }^{77}$, con esculturas del siglo XVII; Murchas, con una imagen del siglo XVIII, y otras, de difícil adscripción como son las de Alhendín o Nieles.

\footnotetext{
76 AA. VV., 2006a: 196.

77 AA. VV., 2006b: 330.
} 


\section{Bibliografía}

AA. VV. Guía artística de Granada y su provincia (I). Sevilla: Fundación José Manuel Lara. (2006a).

AA. VV. Guía artística de Granada y su provincia (II). Sevilla: Fundación José Manuel Lara. (2006b).

Bermejo Martínez, E.: “Las tablas flamencas". En: Pita Andrade, J. M. (coord.) (1994): El libro de la Capilla Real. Granada: Miguel Sánchez.

Biedermann, H.: Diccionario de símbolos. Barcelona: Paidós. (1989).

Calvo Castellón, A.: "Pinturas italianas y españolas". En: Pita Andrade, J. M. (coord.) (1994): El libro de la Capilla Real. Granada: Miguel Sánchez.

Carmona Muela, J.: Iconografía de los santos. Akal: Madrid. (2008).

Chevalier, J. / Gheerbrant, A.: Diccionario de los símbolos. Barcelona: Herder. (1986).

Cruz Cabrera, J. P.: "Calvario (Crucificado de la Esperanza, María y San Juan Evangelista". En: Iuxta Crucem. Arte e iconografía de la Pasión de Cristo en la Granada Moderna (s. XVIXVIII). Granada: Diputación de Granada. (2015).

Cruz Cabrera, J. P.: "La escultura quinientista granadina: de sus albores a Pablo de Rojas". En: Gila Medina, L. (coord.) (2010): La escultura del primer Naturalismo en Andalucía en Hispanoamérica (1580-1625). Madrid: Edit. Arco/Libros.

Cruz Cabrera, J. P.: "La escultura sacromontana". En: López-Guadalupe Muñoz, M. L. / Cruz Cabrera, J. P. / Martínez Fernández, F. J. (2018): La Abadía del Sacromonte: vida y arte en las fuentes del cristianismo moderno. Granada: Fundación Caja Rural.

De la Vorágine, S.: La leyenda dorada, 1. Madrid: Alianza Forma: Madrid. (1982).

Domínguez Cubero, J.: "La rejería en la Capilla Real". En: Calvo Castellón, A. (coord.) (2005): La Catedral de Granada, la Capilla Real y la iglesia del Sagrario (vol. 2). Granada: Cabildo Metropolitano de la Catedral de Granada.

Duchet-Suchaux, G. / Patoureau, M.: La Biblia y los santos. Madrid: Alianza Editorial. (1996). Ferrando Roig, J.: Iconografía de los santos. Barcelona: Ediciones Omega. (1950).

Gallego y Burín, A.: Granada. Guía artística e bistórica de la ciudad. Granada: Edit. Don Quijote. (1982).

García Luque, M.: "Fuentes grabadas y modelos europeos en la escultura andaluza". En: Gila Medina, L. (coord.) (2013): La consolidación del Barroco en la escultura andaluza e bispanoamericana. Granada: Universidad de Granada.

Gila Medina, L. "Alonso de Mena y Escalante (1587-1646). Escultor, ensamblador y arquitecto: nueva aproximación biográfica y nuevas obras". ”. En: Gila Medina, L. (coord.) (2013): La consolidación del Barroco en la escultura andaluza e hispanoamericana. Granada: Universidad de Granada.

Gila Medina, L.: "Bernabé de Gaviria: continuación y ruptura de los ideales de Rojas". En: Gila Medina, L. (coord.) (2010): La escultura del primer Naturalismo en Andalucía en Hispanoamérica (1580-1625). Madrid: Edit. Arco/Libros.

Gómez Moreno, M. (1955): "Diego de Pesquera escultor". En: Archivo Español de Arte, Tomo $\mathrm{n}^{\circ} 28, \mathrm{n}^{\circ} 112$, Madrid, pp. 289-304.

Gómez Moreno, M.: Guía de Granada. Imprenta de Indalecio Ventura: Granada. (1892).

Gómez-Moreno Calera, J. M.: "Evolución de la retablística granadina entre los siglos XVI y XVII". En: Gila Medina, L. (coord.) (2010): La escultura del primer Naturalismo en Andalucía en Hispanoamérica (1580-1625). Madrid: Edit. Arco/Libros.

Gómez-Moreno Calera, J. M.: La iglesia parroquial de la Encarnación de Albolote. Granada: Fundación Francisco Carvajal. (1993).

Gómez-Moreno Calera, J. M. (1997): "Las iglesias del Valle de Lecrín. Estudio arquitectónico (II)". En: Cuadernos de Arte de la Universidad de Granada, no 28, pp. 54.

Gómez-Moreno Calera, J. M. (2002): "Retablo mayor de Santa Isabel la Real de Granada. Estudio histórico-artístico y técnico-estructural". En: Cuadernos de arte de la Universidad de Granada, $\mathrm{n}^{\circ}$ 33, pp. 9-32. 
Interián de Ayala, J.: El pintor christiano y erudito, o Tratado de los errores que suelen cometerse freqüentemente en pintar, y esculpir las Imágenes Sagradas. Madrid: Joachin Ibarra. (1782).

Jiménez Serrano, J.: Guía del artista y del viajero en Granada. Granada: J. A. Linares. (1846).

León Coloma, M. A.: "Bernabé de Gaviria: una nueva propuesta de autoría para el Cristo de la Buena Muerte del Sagrario de Granada". En: Campos y Fernández de Sevilla, F. J. (coord.) (2010): Los crucificados, religiosidad, cofradías y arte. Actas del Simposium 3/6-IX2010. San Lorenzo de El Escorial: Instituto Escurialense de Investigaciones Históricas y Artísticas.

León Coloma, M. A.: "La escultura en la Catedral de Granada". En: Calvo Castellón, A. (coord.) (2005): La Catedral de Granada, la Capilla Real y la iglesia del Sagrario (vol. 2). Granada: Cabildo Metropolitano de la Catedral de Granada.

López-Guadalupe Muñoz, J. J.: "Forma y expresión de los inicios del naturalismo en la escultura granadina. Lecturas y relecturas sobre los Hermanos García”. En: Gila Medina, L. (coord.) (2010c): La escultura del primer Naturalismo en Andalucía en Hispanoamérica (1580-1625). Madrid: Edit. Arco/Libros.

López-Guadalupe Muñoz, J. J.: Imágenes elocuentes: estudios sobre patrimonio escultórico. Granada: Atrio. (2009).

López-Guadalupe Muñoz, J. J. "La Catedral vestida: la arquitectura de retablos". En: Gila Medina, L. (coord.) (2005): El libro de la Catedral de Granada (vol. I). Granada: Cabildo Metropolitano de la Catedral de Granada.

López-Guadalupe Muñoz, J. J. (2006): "Mito e iconografía de la Virgen del Rosario en la Granada Moderna". En: Cuadernos de Arte de la Universidad de Granada, n 37, pp. 161 178.

López-Guadalupe Muñoz, J. J.: "Pablo de Rojas, encrucijada de las escuelas andaluzas". En: Gila Medina, L. (coord.) (2010a): La escultura del primer Naturalismo en Andalucía en Hispanoamérica (1580-1625). Madrid: Edit. Arco/Libros.

López-Guadalupe Muñoz, M. L.: "Piedad desbordante y naturalismo artístico en la Granada de entre siglos: el camino hacia el Barroco". En: Gila Medina, L. (coord.) (2010b): La escultura del primer Naturalismo en Andalucía en Hispanoamérica (1580-1625). Madrid: Edit. Arco/Libros.

Martínez Justicia, Ma. J.: "Las rejas". En: Pita Andrade, J. M. (coord.) (1994): El libro de la Capilla Real. Granada: Miguel Sánchez.

Martínez Medina, F. J.: Cultura religiosa en la Granada renacentista y barroca (estudio iconológico). Granada: Universidad de Granada. (1989).

Martínez Medina, F. J.: "El gran retablo de la Capilla Real". En: Pita Andrade, J. M. (coord.) (1994): El libro de la Capilla Real. Granada: Miguel Sánchez.

Palomino Ruiz, I. / Rodríguez Gutiérrez, F.: "Alhajamiento del templo". En: (2013): La iglesia parroquial de San Juan Bautista de Nigüelas. Aproximación histórico-artística. Nigüelas: Parroquia San Juan Bautista de Nigüelas.

Peinado Guzmán, J. A. (2016): "Nuevas piezas escultóricas en la órbita de Alonso de Mena y su círculo en el entorno granadino". En: Arte y Patrimonio: Revista de la Asociación para la Investigación de la Historia del Arte y del Patrimonio Cultural "Hurtado Izquierdo", no 1, pp. 64-82.

Peinado Guzmán, J. A. / Palomino Ruiz, I (2017): "San Sebastián en el naturalismo escultórico granadino. Estética y símbolo de una iconografía martirial". En: Erebea: Revista de Humanidades y Ciencias Sociales, $\mathrm{n}^{\circ}$ 7, pp. 253-274.

Réau, L.: Iconografía del arte cristiano. Iconografía de los santos. De la G a la O, Tomo 2, vol. 4. Barcelona: Ediciones del Serbal. (1997).

Revilla, F.: Diccionario de iconografía y simbología. Madrid: Ediciones Cátedra. (2007).

Ribadeneira, P. de: Flos Sanctorum, de las vidas de los santos. Madrid: Joachin Ibarra. (1761).

San Agustín: La concordancia de los evangelistas, Libro 1, 6, 9. 
Sánchez-Mesa Martín, D. "La escultura. Monumental. Devocional”. En: Gila Medina, L. (coord.) (2005): El libro de la Catedral de Granada (vol. I). Granada: Cabildo Metropolitano de la Catedral de Granada.

Serrano Ruiz, M.: "El retablo de la Capilla Real". En: Calvo Castellón, A. (coord.) (2005): La Catedral de Granada, la Capilla Real y la iglesia del Sagrario (vol. 2). Granada: Cabildo Metropolitano de la Catedral de Granada.

Tuñí Vancells, J. O. / Alegre, X.: Escritos joánicos y cartas católicas. Estella. Navarra: Verbo Divino. (1995).

Valladar, F. de P.: Guía de Granada. Granada: Imp. y Lib. de la Viuda e hijos de P. V. Sabatel. (1890).

Villena Delgado, J. / Villena Delgado, A.: Arte y tradición en la iglesia parroquial de San Gil y Santa Ana: inventario de su patrimonio. Murcia: Imprenta "La Muleña". (2000). 